\title{
Effect of chelidonine on growth, invasion, angiogenesis and gene expression in head and neck cancer cell lines
}

\author{
RUTH HERRMANN, JEANETTE ROLLER, CHRISTINE POLEDNIK and MARIANNE SCHMIDT \\ Department of Otorhinolaryngology, University of Wuerzburg, D-97080 Wuerzburg, Germany
}

Received March 2, 2018; Accepted May 25, 2018

DOI: $10.3892 / \mathrm{ol} .2018 .9031$

\begin{abstract}
The greater celandine 'Chelidonium majus' and its main alkaloid chelidonine have previously been shown to exert high cytotoxicity against cancer cells. Furthermore, chelidonine is proposed to possess pro-apoptotic and anti-metastatic properties. Within the present study, the effects chelidonine on several HNSCC cell lines, as well as primary cells, were analyzed with respect to growth, migration, angiogenesis and apoptosis. Chelidonine suppressed the growth of all tested HNSCC cell lines, including a paclitaxel-resistant and P-glycoprotein $(M D R 1)$ overexpressing cell line, but not in a clear dose-dependent manner. Mucosal keratinocytes were also strongly affected by chelidonine, while fibroblasts proved to be much more resistant. Chelidonine failed to trigger apoptosis at physiological concentrations in HNSCC cell lines. Based on a spheroid invasion model chelidonine suppressed invasion of FaDu cells effectively on gelatin, fibronectin, collagen I, laminin and Matrige ${ }^{\circledR}$. However, invasion inhibition of the more aggressively invading cell line HLaC78 largely failed. Using the tube formation assay, chelidonine effectively inhibited angiogenesis. Expression analysis revealed an upregulation of the xenobiotic metabolism genes CYP1A1 and MDR1 by chelidonine. In summary, chelidonine appeared to exert only minor impact on head and neck cancer cells. Chelidonine did not produce clear dose-dependent and cell-type specific cytotoxicity nor did it trigger apoptosis strongly.
\end{abstract}

Correspondence to: Dr Marianne Schmidt, Department of Otorhinolaryngology, University of Wuerzburg, 11 Josef-SchneiderStraße, D-97080 Wuerzburg, Germany

E-mail: schmidt_m2@ukw.de

Abbreviations: ECM, extracellular matrix; HNSCC, head and neck squamous cell carcinoma; OSCC, oral squamous cell carcinoma; MDR-1, gene locus multi drug resistance-1, coding for p-glycoprotein; VEGF, vascular endothelial growth factor

Key words: chelidonine, cancer, carcinoma, head and neck, herbal drug, metastasis, in vitro, HNSCC, gene expression array

\section{Introduction}

Head and neck squamous cell carcinoma (HNSCC) is one of the leading causes of cancer deaths worldwide. In general the overall cure of HNSCC is less than $50 \%$ and in case of metastasis, patients only have a life expectancy of 6 to 10 months (1). According to an analysis in 2009 of over 3,000 cases of primary head and neck tumours in Germany, the outcome has not improved significantly from 1995 to 2006, despite new treatment strategies. Therefore substances suppressing tumour growth and invasion would be desirable.

Chelidonium majus, the greater celandine has been used for hundreds of years in monastic medicine against several widespread diseases and is described in detail in Jonathan Hartwell's compendium (2) 'Plants used against Cancer'.

Chelidonine is an isoquinoline alkaloid and the main alkaloid of Chelidonium majus. It has been reported to have anti-cancer properties in a variety of tumor systems. Chelidonine and a Chelidonium majus alkaloid extract, were shown to overcome drug resistance by inhibition of the expression of p-glycoprotein $(M D R-1)$ and several enzymes of the cytochrome P450 system, involved in xenobiotic metabolism in leukemia and colon cancer cells and the induction of caspase-dependent apoptosis (3). However, published results concerning the effectivity and cancer-selectivity of chelidonine are still controversial. However, until now C. majus alkaloids have not been tested as possible therapeutic agents in HNSCC cell lines and corresponding non-malignant primary cells of the mucosa of the upper respiratory tract.

We analyzed the cytotoxicity of the chelidonine, triggering of apoptosis as well as the impact on differential gene expression. Furthermore the influence of chelidonine on the motility of HNSCC cells was studied in a 3-dimensional, spheroid-based invasion assay. Results are discussed critically with respect to previously published projects.

\section{Materials and methods}

Reagents. Chelidonine was purchased at Sigma-Aldrich; Merck KGaA, Darmstadt, Germany). A $50 \mathrm{mM}$ stock solution was prepared in absolute ethanol and stored in aliquots at $-20^{\circ} \mathrm{C}$.

Cell lines and cell culture. The cell line FADU originating from a hypopharyngeal carcinoma was grown with 
RPMI-1640 medium (Seromed, Munich, Germany), supplemented with $10 \%$ fetal bovine serum (FBS). HLaC78 and HLaC79 cell lines originated from larynx carcinoma (4) and were kept in RPMI-1640 medium. HSmC78 was established from a submandibular gland carcinoma (5) and also cultured with RPMI/10\% FBS. HLaC79-Tax was obtained by selective sub-cultivation of a paclitaxel-resistant clone. It was kept as its original cell line supplemented with 10 (HLaC79-Tax) paclitaxel. As primary cells mucosal fibroblasts and keratinocytes were used. Fibroblast cultures were generated by explant cultures from tonsil specimen in Dulbecco's modified Eagle's medium (DMEM)/10\% FBS. Isolation of keratinocytes was performed as described (6). Keratinocytes were propagated in Keratinocyte Medium 2 (PromoCell, Heidelberg, Germany).

Cell viability and proliferation assay. Cells were seeded at 5,000 cells/well in 96-well plates. They were treated with increasing concentrations of chelidonine for $48 \mathrm{~h}$. Cell proliferation was measured after $48 \mathrm{~h}$ by replacing the culture medium with medium containing $1 \mathrm{mg} / \mathrm{ml}$ MTT. After $4 \mathrm{~h}$ incubation, MTT-staining solution was replaced by isopropanol and cells were incubated at $37^{\circ} \mathrm{C}$ for $45 \mathrm{~min}$. The colour conversion of MTT to a blue formazon dye was measured with an ELISA reader at a wavelength of $570 \mathrm{~nm}$. The amount of formazon dye is in direct proportion to the number of metabolically active cells in the culture. Relative toxicity was calculated as $\%$ surviving cells by setting control cells treated with vehicle as $100 \%$ surviving cells.

Growth assay of $3 D$ cell cultures. Tumour spheroids were generated by seeding 2,000 cells/well of FADU cells on ultra-low-attachment (ULA) 96-well round-bottomed plates (Corning Life Sciences BV, Amsterdam, Netherlands). They were incubated with chelidonine in increasing concentrations (10, 25 or $50 \mu \mathrm{M}$ chelidonine). Controls were incubated with corresponding amounts of $70 \% \mathrm{EtOH}$. Images were captured every $24 \mathrm{~h}$ for 7 days. Size of spheroids was measured with ImageJ software [National Institutes of Health (NIH), Bethesda, MD, USA].

In vitro motility assays. Tumour spheroids were generated by seeding 5,000 cells/well of HLaC78 or FADU on ultra-lowattachment (ULA) 96-well round-bottomed plates (Corning Life Sciences BV). For the migration assay spheroids of HLaC78 and FADU were placed on different extracellular matrix substrates. The surface of flat-bottomed 96-well plates were coated with $0.1 \%$ gelatin, $5 \mu \mathrm{g} / \mathrm{ml}$ fibronectin, $50 \mu \mathrm{g} / \mathrm{ml}$ laminin, $50 \mu \mathrm{g} / \mathrm{ml}$ collagen I (all purchased from Sigma-Aldrich; Merck KGaA) or $125 \mu \mathrm{g} / \mathrm{ml}$ Matrigel $^{\circledR}$ (Becton-Dickinson, Heidelberg, Germany) for $2 \mathrm{~h}$ at room temperature. Wells were washed twice with phosphate-buffered saline (PBS) and subsequently blocked with $1 \%$ bovine serum albumin in PBS for $1 \mathrm{~h}$. On ULA plates cultivated $72 \mathrm{~h}$ old spheroids of both cell lines were manually transferred to the coated wells with a multichannel pipette. Spheroids were incubated with or without chelidonine. Migration was recorded by photographing spheroids after 1 and $18 \mathrm{~h}$ with a Leica DMI 4000 inverted fluorescence microscope (Leica Microsystems, Wetzlar, Germany). Quantification of migrated cell layers was carried out with the ImageJ software (NIH).
RNA extraction and RNA quality control. RNA of treated and control cell cultures was isolated with the RNeasy Kit (Qiagen GmbH, Hilden, Germany) according to the manufacturer's instructions. For using it in expression arrays, RNA quality was assessed with the RNA 6000 Nano Kit using the Bioanalyzer 2100 instrument (Agilent Technologies, Böblingen, Germany). RNA integrity numbers (RINs) of our samples ranged between 9.4 and 9.9 .

Microarray analysis. For microarray hybridization, $100 \mathrm{ng}$ total RNA were amplified and labelled using the IVT Express Kit and hybridized to GeneChip PrimeView Human Gene Expression arrays (both from Affymetrix, Inc., Santa Clara, CA, USA) according to the manufacturer's instructions.

Raw microarray data was background corrected, normalized and summarized to probe set expression values using the Robust Multi-array Average (RMA) algorithm $(7,8)$. Data preprocessing and calculation of fold changes between treated and untreated expression values was performed with the Affymetrix Expression Console and the Affymetrix Transcriptome analysis Console (Affymetrix; Thermo Fisher Scientific, Inc., Waltham, MA, USA). Microarray data were deposited in MIAME-compliant form at Gene Expression Omnibus (http://www.ncbi.nlm.nih.gov/geo) with the identifier GSE107464.

Taqman quantitative PCR. In order to analyze expression alterations caused by chelidonine HNSCC cell lines FADU, $\mathrm{HLaC} 78$ and $\mathrm{HSmC} 78$ cell lines were treated for $48 \mathrm{~h}$ with chelidonine $(10 \mu \mathrm{M})$. RNA was subsequently isolated (see above) and Real-Time TaqMan ${ }^{\circledR}$ PCR (AppliedBiosystems.com) was performed in triplicates on a Real-time PCR cycler (Applied Biosystems, Darmstadt, Germany) using the TaqMan gene expression assays for ABCB1 (MDR-1), CYP1A1 and CYP1B1, CYP3B4, GSTP1 and caspase-3. Relative quantification was calculated according to the $2^{-\Delta \Delta \mathrm{Cq}}$ method (9). Expression values were normalized to the expression of GAPDH as an endogenous control which proved to be expressed most stably throughout the cell lines.

Tube formation assay. The ability of endothelial cells to form three-dimensional capillary-like structures in vitro was analysed with the tube formation assay.

Ibidi angiogenesis-slides (15-well; Ibidi GmbH, Munich, Germany) were coated with growth factor reduced basement membrane extract (BME; Trevigen, Gaithersburg, MD, USA). After polymerization of BME, the gels were overlaid with growth medium containing $1 \times 10^{4}$ HUVECs and with or without chelidonine. Cells were incubated for $6 \mathrm{~h}$ and images were captured. Evaluation of pictures was performed by Wimasis GmbH (Munich, Germany). For quantification, four parameters were analyzed: Tube length, number of branching points, covered area and number of loops.

Statistical analysis. All statistical analyses and graphs were performed using GraphPad Prism 4 (GraphPad Software, Inc., La Jolla, CA, USA). Data are presented as the mean \pm standard deviation of three independent MTT experiments or eight measured spheroids. An unpaired t-test (angiogenesis, migration measurements) or ANOVA with Dunnett's multiple 

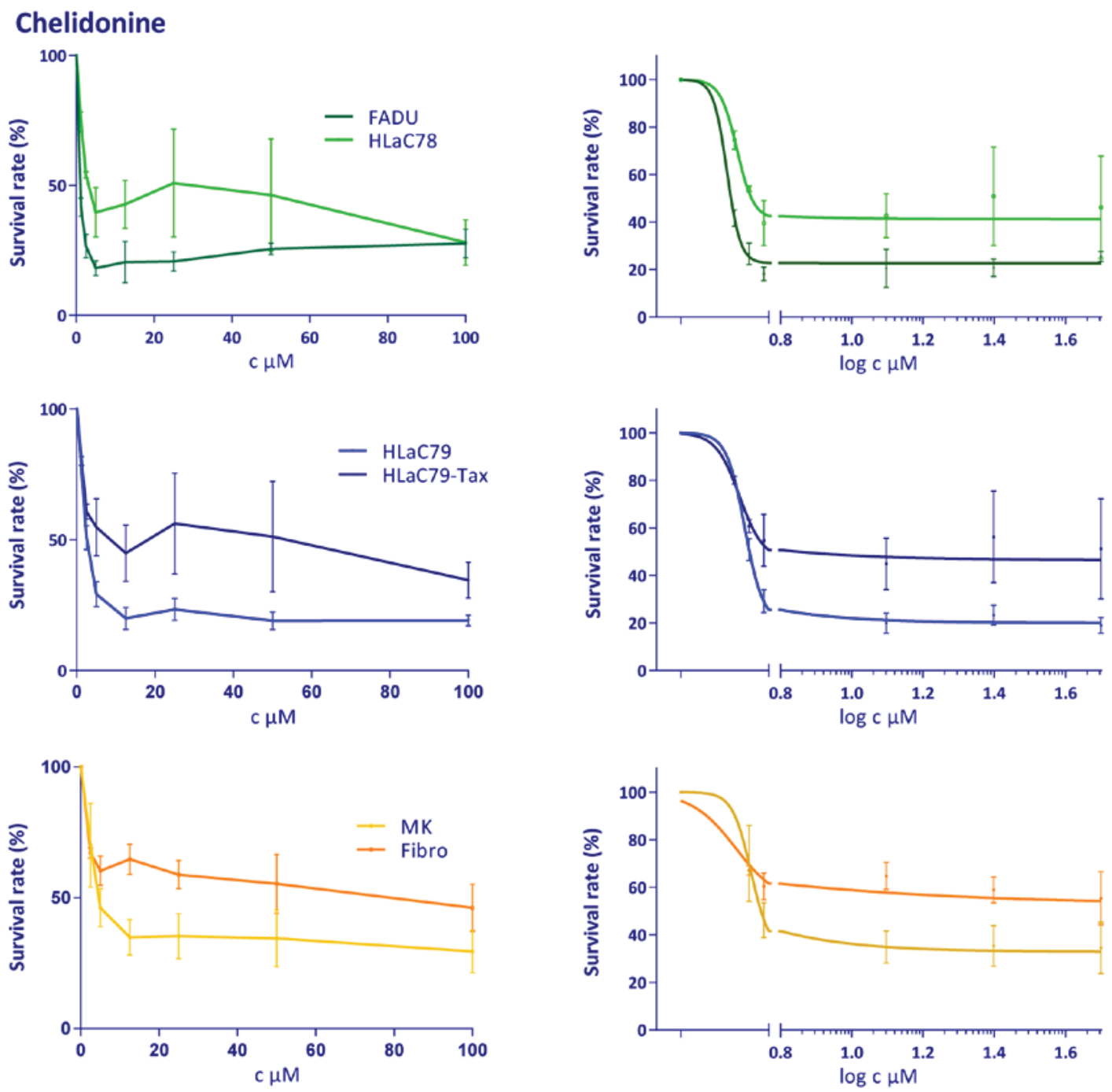

Figure 1. Cytotoxicity of chelidonine in increasing concentrations on HNSCC cell lines HLaC78, FADU, HLaC79, HLaC79-Tax and primary mucosal keratinocytes (MK) and fibroblasts (Fibro) measured with the MTT assay. Data are presented as the mean of three independent experiments + standard deviation Left panel, dose-response curves; right panel, statistical curve fitting/calculation of $\mathrm{EC}_{50}$.

comparison test (qRT-PCR) were used. $\mathrm{P}<0.05$ was considered to indicate a statistically significant difference.

\section{Results}

Cytotoxicity. The cell lines FADU, HLaC78, HLaC79, HLaC79-Tax and primary mucosal keratinocytes and fibroblasts were treated with increasing concentrations of chelidonine $(1.25,2.5,5,12.5,25,50$ and $100 \mu \mathrm{M})$. Cell viability and cytotoxicity were measured with the MTT assay (Fig. 1). Mean percentage inhibition was calculated from at least three independent experiments.

MTT assays with chelidonine revealed no clear dosedependent decrease in cell survival. Survival rates decreased rapidly with low doses and remained approximately constant from the $10 \mu \mathrm{M}$ dose level on (Fig. 1). A complete growth inhibition could not be achieved in any cell line, even at very high doses. Comparison of HLaC79 with its corresponding paclitaxel-resistant clonal descendant revealed a significantly higher resistance of the drug-resistant cell line at doses exceeding $10 \mu \mathrm{M}$ (Fig. 1). HLaC78 proved to be more resistant

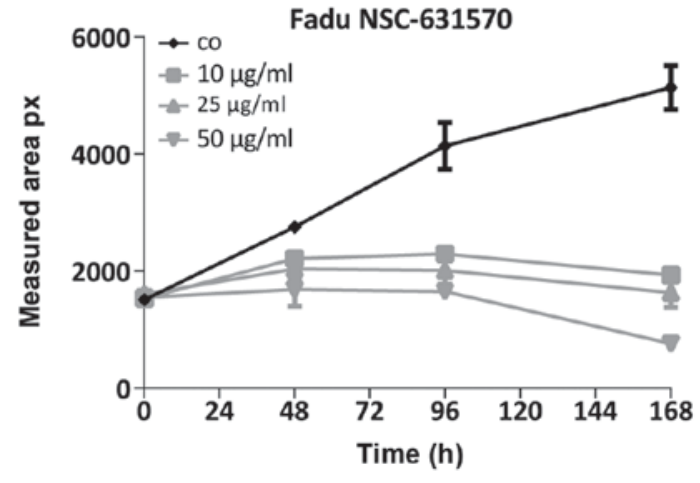

Figure 2. Cytotoxicity of chelidonine at increasing concentrations on FaDu spheroids determined by measuring the spheroids size. Data are presented as the mean of 8 spheroids + standard deviation (Dose-response curve).

to chelidonine treatment than FaDu (Fig. 1). Mucosal keratinocytes were similarly growth inhibited as HNSCC cell lines. Growth inhibition similarly stagnated at concentrations higher than $10 \mu \mathrm{M}$ (Fig. 1). Fibroblasts proved to be less susceptible 
A $\mathrm{FaDu}+1 \mu \mathrm{M}$ chelidonine

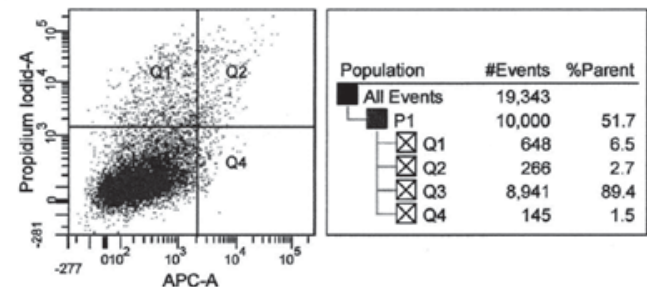

FaDu control

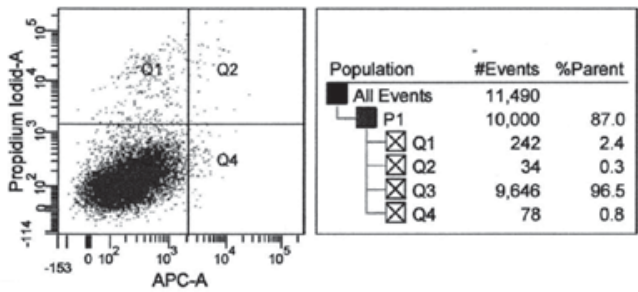

B $\mathrm{FaDu}+10 \mu \mathrm{M}$ chelidonine

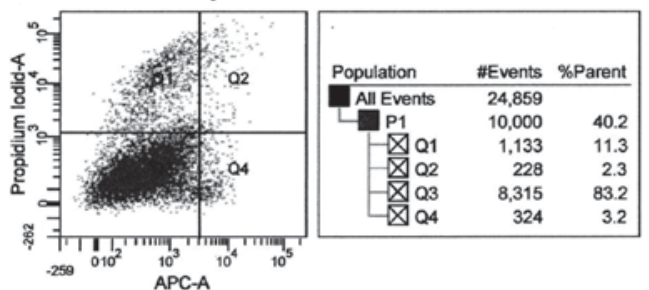

FaDu control

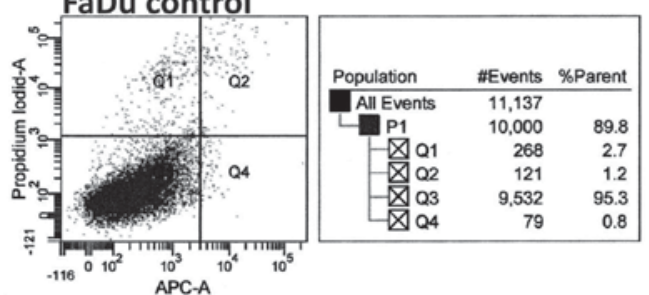

HLaC78 + $1.6 \mu \mathrm{M}$ chelidonine

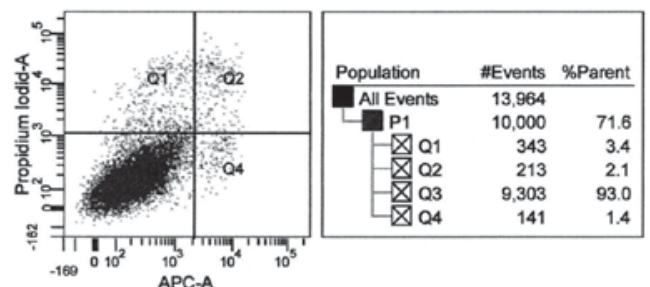

HLaC78 control

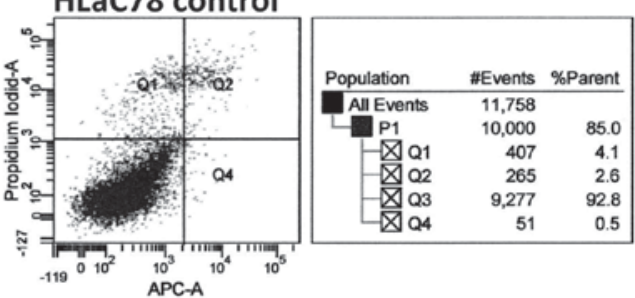

HLaC78 + $10 \mu \mathrm{M}$ chelidonine

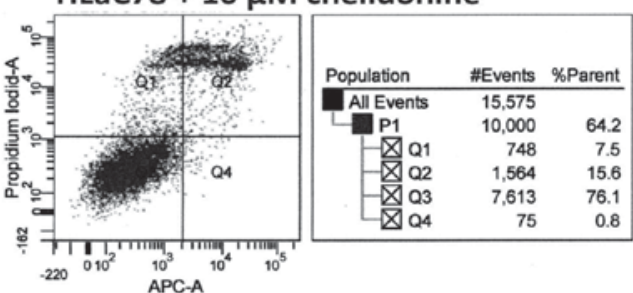

HLaC78 control

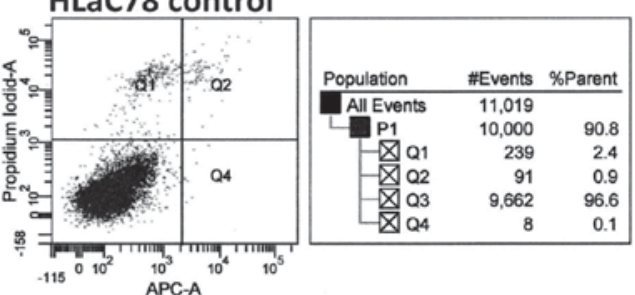

Figure 3. FACS analysis using the APC Annexin V kit of chelidonine treated FaDu and HLaC78 cells. All conditions were determined in triplets; one representative sample of each condition is shown. $\mathrm{FaDu}$ and $\mathrm{HLaC} 78$ cells were incubated for $24 \mathrm{~h}$ with corresponding $\mathrm{EC}_{50}(\mathrm{~A})$ or the increased concentration of $10 \mu \mathrm{M}$ (B) of chelidonine. Chelidonine triggered indefinite changes in the cell population towards cell death but not specifically apoptotic events (Q4).

to chelidonine treatment. Due to the steep curve progression at low concentrations and the flat plateau at higher concentrations, $\mathrm{EC}_{50}$ concentrations of $1.0 \mu \mathrm{M}(\mathrm{FaDu})$ and $1.6 \mu \mathrm{M}(\mathrm{HLaC} 78)$ with very wide ranges were calculated by graphpad prism.

Growth inhibition of FaDu spheroids. Growth inhibition in spheroids was determined by measuring the size of the spheroids every $24 \mathrm{~h}$ after treatmentwith different concentrations of chelidonine. Interestingly growth dynamics of FaDu spheroids resembled those of monolayer cultures. The growth of spheroids was diminished by $10 \mu \mathrm{m}$ chelidonine, while higher concentrations did not enhance growth inhibition (Fig. 2).

Apoptosis. Apoptosis of chelidonine treated and untreated FaDu and HLaC78 cells were determined after $24 \mathrm{~h}$ of incubation using the Annexin V staining kit and FACS analysis.

Despite killing cells at the $\mathrm{EC}_{50}$ doses $(1 \mu \mathrm{M}$ in $\mathrm{FaDu}$, $1.6 \mu \mathrm{M}$ in HLaC78), as demonstrated by the preceding MTT assays, chelidonine did not trigger apoptosis (Fig. 2A). As the $\mathrm{EC}_{50}$ of chelidonine couldn't be determined exactly by statistical calculation (see above), the effect of a higher concentration of chelidonine $(10 \mu \mathrm{M})$ was also tested. Using this higher concentration, the apoptotic cell population of FaDu cells was rising to $3.2 \%$. In contrast, in $\mathrm{HLaC} 78$ indefinite (Q1) and late apoptotic/necrotic cell death fractions (Q2) increased, but a significant increase of pre-apoptotic cell fractions did not occur.

Representative examples of FaDu and HLaC78 FACS results are shown in Fig. 3.

Cell motility on extracellular matrix (ECM) proteins. Investigation of invasion and motility was carried out using spheroid-based experiments. In contrast to the commonly used Boyden Chamber assay this kind of invasion measurement proved to be reliable and reproducible and considers substrate specificity.

Spheroids of FADU and HLaC78 were grown in ultralow-attachment-plate (ULA-plate) wells and subsequently transferred manually to wells, coated with different ECM substrates: gelatin, fibronectin, laminin, collagen I and Matrige ${ }^{\circledR}$ and treated with or without chelidonine. Images of the cells were captured after attachment of the spheroids to $\operatorname{ECM}(1 \mathrm{~h}, \mathrm{t}=0)$ and after $18 \mathrm{~h}(\mathrm{t}=18)$.

For quantification of cells migrating out of spheroids the coated wells at $\mathrm{t}=0$ and $\mathrm{t}=18$ were photographed and outgrown 

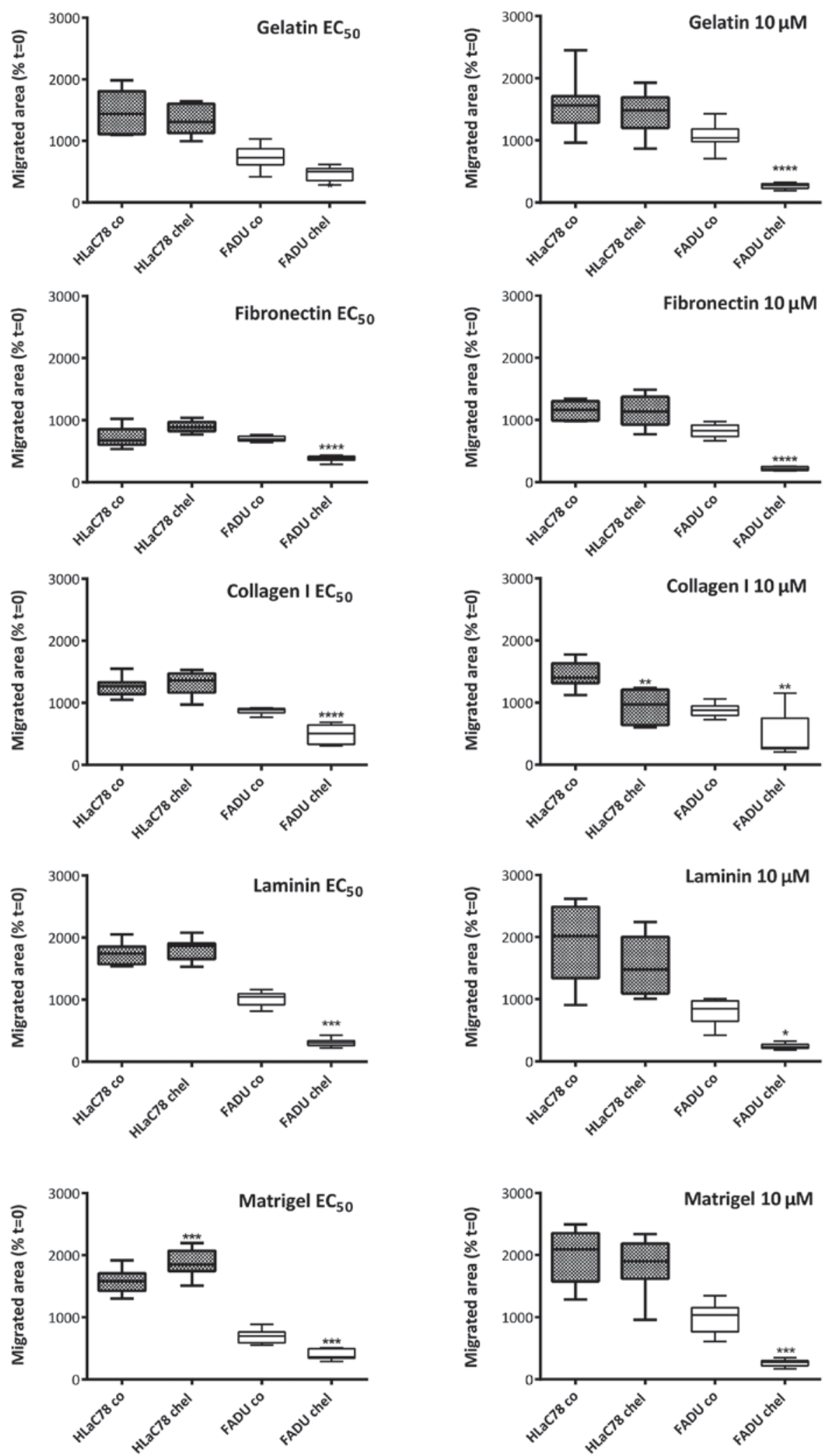

Figure 4. Migration ability of chelidonine treated HLaC78 and FaDu cells on different ECM surfaces. Spheroids were treated with correspoding EC $\mathrm{C}_{50}$ $(1 \mu \mathrm{M} \mathrm{FaDu}, 1.6 \mu \mathrm{M} \mathrm{HLaC} 78)$ or $10 \mu \mathrm{M}$ for $18 \mathrm{~h}$. Data are presented as the mean of 8 spheroids + standard deviation. Calculation of migration of the cells was performed by setting spheroid area as $100 \%$ at $\mathrm{t}=0 .{ }^{* * * *} \mathrm{P}<0.0001,{ }^{* * *} \mathrm{P}<0.001,{ }^{* *} \mathrm{P}<0.01,{ }^{*} \mathrm{P}<0.05$ statistically significant values (unpaired $\mathrm{t}$-test).

areas were measured with ImageJ software (area calculation). For each condition 8 spheroids were measured.

For calculation of cell motility the area at $\mathrm{t}=0$ was set at $100 \%$ and the percentage of invaded area was calculated. Results are graphically summarized in Fig. 4.
At the calculated $\mathrm{EC}_{50}$ doses chelidonine did not suppress the migration of $\mathrm{HLaC} 78$ cells. FaDu cells instead were suppressed in their migration activity on all applied ECM proteins in the presence of $1 \mu \mathrm{M}$ chelidonine (Fig. 5). The elevated dose of $10 \mu \mathrm{M}$ significantly decreased migration 

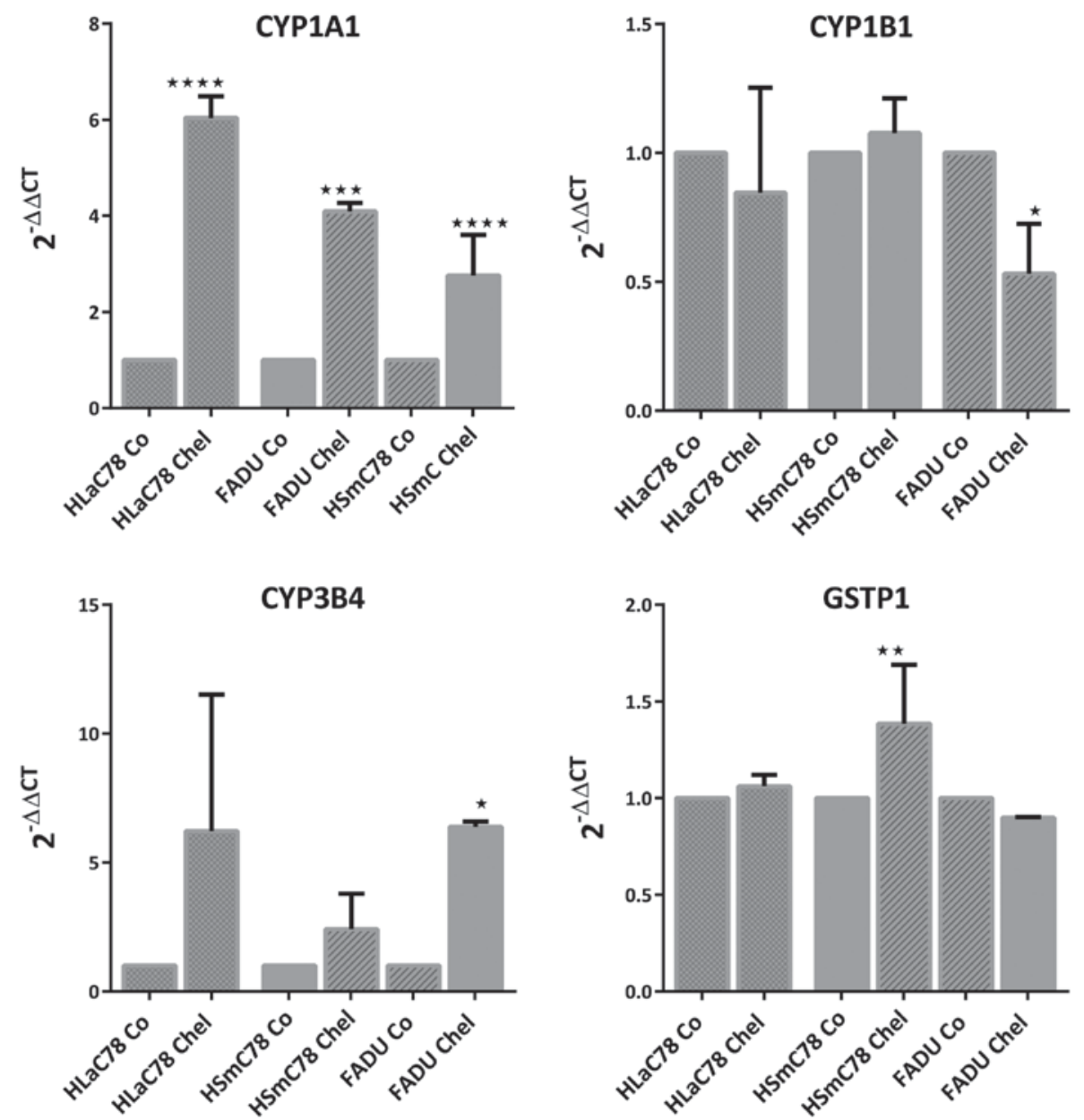

Figure 5. TaqMan RT-PCR analysis of chelidonine $(10 \mu \mathrm{M})$ treated FaDu, HLaC78 and HSmC78 cells. Gene expression of CYP1A1, CYP1B1, CYP3B4 and GSTP1 were determined by TaqMan Real-Time PCR in comparison to untreated cells using double $\triangle \mathrm{CT}$ analysis. Data are presented as the mean of three measurements + standard deviation with ${ }^{* * * *} \mathrm{P}<0.0001,{ }^{* * *} \mathrm{P}<0.001,{ }^{* *} \mathrm{P}<0.01,{ }^{*} \mathrm{P}<0.05$; statistically significant values (ANOVA Dunnett's multiple comparison test).
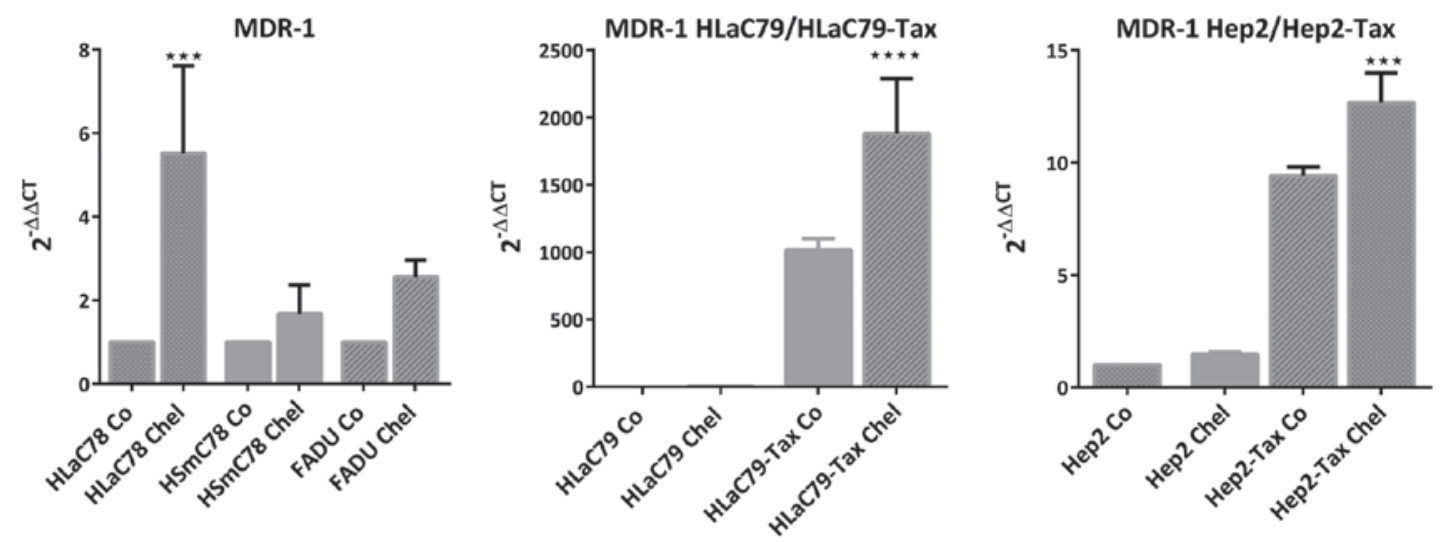

Figure 6. TaqMan RT-PCR analysis of chelidonine $(10 \mu \mathrm{M})$ treated FaDu, HLaC78 and HSmC78 cells. Gene expression of MDR1 was determined by TaqMan Real-Time PCR in comparison to untreated cells using double $\Delta C T$ analysis. ${ }^{* * * * *} \mathrm{P}<0.0001,{ }^{* * * *} \mathrm{P}<0.001$, statistically significant values, ANOVA Dunnett's multiple comparison test.

of $\mathrm{FaDu}$ cells as expected. In the highly invasive cell line HLaC78 even $10 \mu \mathrm{M}$ chelidonine failed to inhibit migration on four of five substrates.

Gene expression. Microarrays of chelidonine treated $\mathrm{FaDu}$ cells did not reveal significant changes in expression of genes, which could be assigned to particular pathways or cell processes, even at the elevated dose of $10 \mu \mathrm{M}$. Complete Data sets of microarrays are deposited at Gene Expression Omnibus (http://www.ncbi.nlm.nih.gov/geo) with the identifier GSE107464. For this reason we decided to examine the expression of a set of genes, previously reported to be 


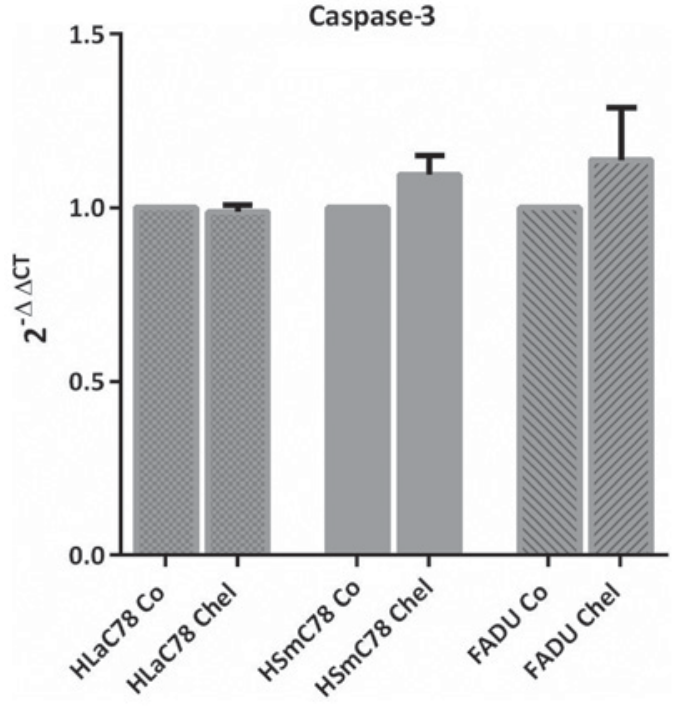

Figure 7. TaqMan RT-PCR analysis of chelidonine $(10 \mu \mathrm{M})$ treated $\mathrm{FaDu}$, HLaC78 and HSmC78 cells. Gene expression of caspase-3 was determined by TaqMan Real-Time PCR in comparison to untreated cells using double $\Delta \mathrm{CT}$ analysis. Data are presented as the mean of 3 measurements + standard deviation. Expression changes were not statistically significant (ANOVA Dunnett's multiple comparison test).

differentially expressed upon chelidonine treatment (3). Thus, we analyzed the expression of enzymes of drug metabolism p-glycoprotein (ABCB1/mdr-1), cytochrome P450, family 1 , members $\mathrm{A} 1$ and $\mathrm{B} 1$, and family 3 , member A4 (CYP1A1, CYP1B1, CYP3A4) as well as gluthation-Stransferase P1 (GSTP1). All these genes have been reported to be strongly downregulated by chelidonine in Caco- 2 colon carcinoma cells (3), suggesting reduced drug resistance in chelidonine treated cells. The same group has shown that caspase- 3 was upregulated in Caco- 2 cells. Therefore, we studied expression of caspase- 3 in HNSCC upon chelidonine treatment.

None of the cytochrome P450 genes was downregulated by chelidonine in the HNSCC system (Fig. 5). Similarly p-glycoprotein (MDR1) was upregulated by chelidonine in HNSCC cell lines. Particularly in MDR1-overexpressing taxol-resistant cell lines HLaC79-Tax and Hep2-Tax transcription of the MDR-1 gene increased significantly (Fig. 6).

Caspase-3 expression, which had been reported to be upregulated by chelidonine (3) reflects the results of the current apoptosis assay (see Fig. 3) and was not significantly upregulated in HNSCC cell lines after chelidonine treatment (Fig. 7).

Angiogenesis. The anti-angiogenic potential of chelidonine was determined using the tube formation assays. The tube formation ability of human umbilical vein endothelial cells (HUVEC) on Matrigel substrate in presence of $2 \mu \mathrm{M}$ chelidonine was examined. HUVEC showed disturbed tube formation in response to low dose chelidonine (Fig. 8). Quantification of inhibition using the WimTube image analysis revealed a significant decrease in total tube length, total branching points, total loops and covered area for chelidonine. Quantitative results are summarized in Fig. 8.

\section{Discussion}

Within the present study, the main alkaloid of Chelidonium majus, chelidonine, was examined for its effect on HNSCC cell lines in vitro. Particularly, the influence of this drug with respect to cell growth, apoptosis, migration and angiogenesis on tumor cells as well as its cytotoxicity against primary cells and tumour cells in a 3-dimensional context have been investigated.

Chelidonine has previously been shown to act cytotoxic on chemo-sensitive and chemo-resistant leukaemia, colon cancer, hepatic cancer and cervical cancer cell lines (3). Within the present study chelidonine $\mathrm{EC}_{50}$ values ranged between 0.14 and $111 \mu \mathrm{M}$, with the highest resistance in p-glycoprotein expressing cell lines.

Here dose-response curves of chelidonine showed a characteristic course through all cell lines/primary cell cultures with a very steep decrease of viability between 0 and $10 \mu \mathrm{M}$ doses. Also characteristic was a plateau in dose-response curves, reached at $\sim 0 \mu \mathrm{M}$ chelidonine. In a few cell lines viability even increased at higher doses (data not shown).

This observation is nearly identical to that of Panzer et al (10), who also failed to get clear dose-dependent viability inhibition. The results in monolayer cultures were confirmed by the spheroid growth assay, where maximal growth suppression was reached with $10 \mu \mathrm{m}$ chelidonine. Increased doses did not enhance cytotoxic effects further. Furthermore, Panzer et al (10) described a more pronounced inhibitory effect of chelidonine on normal monkey kidney cells than on foreskin fibroblasts, which corresponds to the low sensitivity of mucosal fibroblasts in contrast to mucosal keratinocytes towards chelidonine in the present study. Therefore it seems that chelidonine is not selectively cytotoxic for tumor cells.

In contrast to the study of El-Readi (3) and others $(11,12)$, chelidonine was not able to trigger apoptosis in HNSCC cell lines significantly. Caspase- 3 was not upregulated by chelidonine in HNSCC cell lines, thus confirming the results of the apoptosis assay (Fig. 3).

Differential gene expression was investigated using Affymetrix prime view cDNA arrays with the most sensitive cell line $\mathrm{FaDu}$ and the $\mathrm{EC}_{50}$ concentration $1 \mu \mathrm{M}$ as well as $10 \mu \mathrm{M}$ chelidonine. Data analysis using the Transcription Analysis Console (Affymetrix) revealed no clear activation or repression of genes assignable to particular pathways or cell processes. For this reason we decided to refer to the only published gene expression study on chelidonine (3) and analyzed expression of some key genes of drug metabolism and apoptosis, which have been shown to be strongly influenced by chelidonine in Caco-2 cells (3). The genes, involved in drug metabolism cytochrome P450 1A1, 1B1, 3A4 (CYP1A1, CYP1B1, CYP3A4 and glutathione-S-transferase P1 (GSTP1) as well as the multi-drug-resistance mediating p-glycoprotein (MDR1) have been reported to be downregulated by chelidonine in Caco- 2 colon carcinoma cells. The authors concluded that the tested colon cancer cells overcome drug resistance upon chelidonine treatment. With HNSCC cell lines these results could not be confirmed. Chelidonine clearly increased expression of the xenobiotic metabolism genes CYP1A1 and CYP3A4, whereas expression of GSTP1 

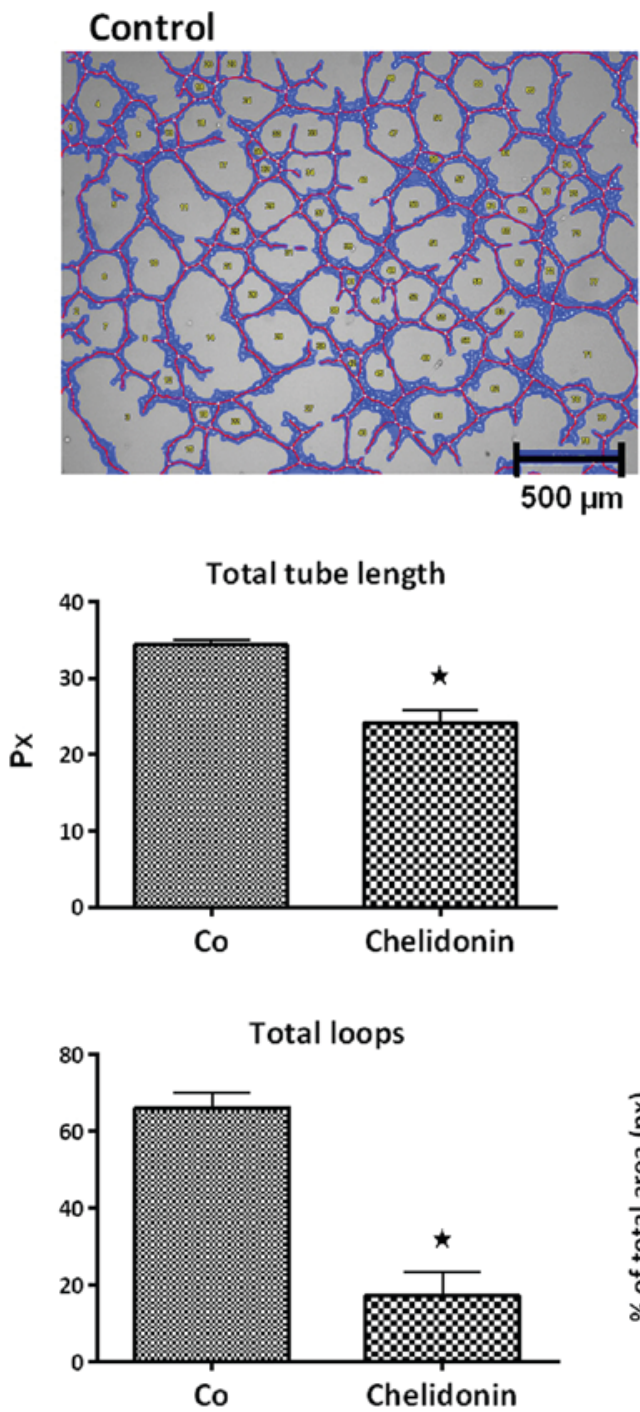

\section{Chelidonine}

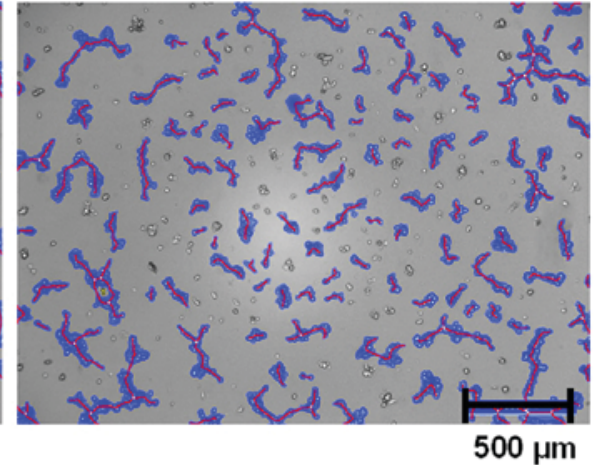

Total branching points
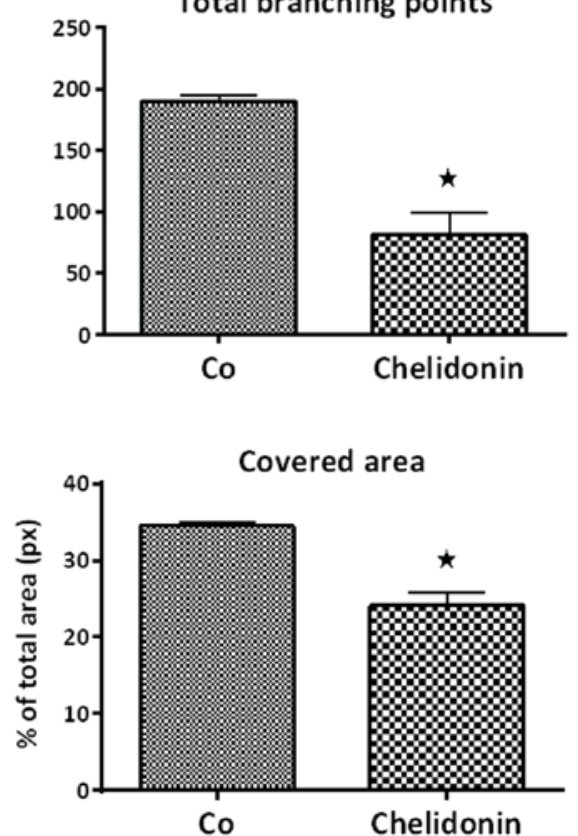

Figure 8. Anti-angiogenic potential of chelidonine using the tube formation assay. HUVEC were incubated for $5 \mathrm{~h}$ with or without $1 \mu \mathrm{M}$ chelidonine and photographed. Image analysis revealed significant decrease of total tube length, total branching points, total loops and covered area (\%) by chelidonine treatment compared to untreated HUVEC tube formation control. Data are presented as the mean of 5 tube formation assays + standard deviation ${ }^{*} \mathrm{P}<0.05$, statistically significant values (unpaired t-test). Size bar=500 $\mu \mathrm{m}$.

and CYP1B1 remained unchanged in most cases. MDR1 was significantly upregulated in drug-resistant cell lines HLaC79-Tax and Hep2-Tax upon chelidonine treatment. As a consequence, the results of the present study would indicate an increased drug resistance in HNSCC cell lines caused by chelidonine in vitro. The role of the mainly extrahepatic occurring CYP1 family, which belongs to the cytochrome P450 system, and particularly that of CYP1A1 is controversially discussed. CYP1A1, mainly occurring in non-hepatic tissue, has been shown to be involved in carcinogenesis by activating pro-carcinogens, such as N-nitrosamines. On the other hand it has been shown to act cancer-preventive by metabolizing and thus activating dietary compounds, such as flavonoids [for review see Androutsopoulos et al (13)]. Therefore, it could not be decided, if the in HNSCC cells observed overexpression of CYPlA1, due to chelidonine, contributes to the cytotoxicity of the drug or to a progression in drug resistance.

Tube formation assay with HUVEC cells, plated on BME and cultivated with chelidonine, revealed a significant inhibition of angiogenesis. To date, there are no comparable studies on angiogenesis in connection with chelidonine. In the present study, however, we have to consider, that the nature of the tube formation assay is merely suitable for the evaluation of endogenous inhibition processes within the endothelial cells. No other cells or growth factors participated in this experimental setup. These possible endogenous angiogenesis inhibition may be based on the interference with endothelial adhesion factors, intrinsic pathways or other targets in endothelial cells (14).

Cell migration is crucial for tumor formation and progression by invading surrounding tissues (15). Particularly in HNSCC, this process can be life-threatening, even without (distant) metastasis. The 3D based spheroid migration assay used in the present study, reflects the heterogenic tumor microenvironment better than commonly used Transwellbased assays. Additionally, it considers interactions with different ECM proteins. Tumor cells organized as 3D spheroids, mimic non-vascularized tumors with discrete zones of growing and quiescent cells, as well as a necrotic center (16). The cell lines HLaC78 and FaDu show the tendency to leave the spheroid as a model for multicellular tissue upon getting 
in contact with ECM-coated surfaces, with HLaC78 invading more aggressive than $\mathrm{FaDu}$. This tumor invasion model was used to evaluate the influence of chelidonine on the migration on gelatin, laminin, fibronectin, collagen type I and Matrigel ${ }^{\circledR}$. Chelidonine effectively suppressed migration of $\mathrm{FaDu}$ on all ECM surfaces tested, even at the $\mathrm{EC}_{50}$ dose of $1 \mu \mathrm{m}$. In the invasive cell line HLaC78 however, only the elevated dose of $10 \mu \mathrm{m}$ chelidonine was sufficient to inhibit migration on collagen. This observation is in agreement with the findings of Kim et al (17), who previously proposed chelidonine to be a potential drug for treatment of metastatic/invasive tumors, on basis of in vitro studies with breast cancer cell lines.

Summarizing our results, chelidonine turned out to be disappointing concerning cancer cell type specificity. Both primary and cancer cells were affected by chelidonine. There was no clear dose-dependent action and a strong apoptotic reaction could not be achieved in HNSCC cell lines.

\section{Acknowledgements}

Not applicable.

\section{Funding}

No funding was received.

\section{Availability of data and material}

The datasets used and/or analyzed during the current study are available from the corresponding author on reasonable request.

\section{Authors' contributions}

RH performed all cell culture experiments and RT-qPCR. JR assisted with the molecular biological experiments. CP was responsible for cell culture maintenance. MS evaluated the results and assisted in writing the manuscript.

\section{Ethics approval and consent to participate}

Written informed consent was obtained beforehand, and the study was approved by the Institutional Ethics Committee on human research of the Julius-Maximilians-University Wuerzburg (Approval no. 16/06).

\section{Consent for publication}

Not applicable.

\section{Competing interests}

The authors declare that they have no competing interests.

\section{References}

1. Goerner M, Seiwert TY and Sudhoff H: Molecular targeted therapies in head and neck cancer-an update of recent developments. Head Neck Oncol 2: 8, 2010.
2. Hartwell JL: Plants used against cancer a survey Quarterman Publications, Lawrence, Mass, 1982.

3. El-Readi MZ, Eid S, Ashour ML, Tahrani A and Wink M: Modulation of multidrug resistance in cancer cells by chelidonine and Chelidonium majus alkaloids. Phytomedicine 20: 282-294, 2013.

4. Zenner HP, Lehner W and Herrmann IF: Establishment of carcinoma cell lines from larynx and submandibular gland. Arch Otorhinolaryngol 225: 269-277, 1979.

5. Zenner HP, Herrmann IF, Bremer W and Stahl-Maugé C: Head and neck carcinoma models. In vivo reproduction in athymic mice and in vitro culture. Acta Otolaryngol 95: 371-381, 1983.

6. Schmidt M, Grünsfelder P and Hoppe F: Induction of matrix metalloproteinases in keratinocytes by cholesteatoma debris and granulation tissue extracts. Eur Arch Otorhinolaryngol 257: 425-429, 2000

7. Irizarry RA, Hobbs B, Collin F, Beazer-Barclay YD, Antonellis KJ, Scherf U and Speed TP: Exploration, normalization, and summaries of high density oligonucleotide array probe level data. Biostatistics 4: 249-264, 2003.

8. Bolstad BM, Irizarry RA, Astrand M and Speed TP: A comparison of normalization methods for high density oligonucleotide array data based on variance and bias. Bioinformatics 19: 185-193, 2003.

9. Livak KJ and Schmittgen TD: Analysis of relative gene expression data using real-time quantitative PCR and the $2^{-\Delta \Delta C \mathrm{~T}}$ method. Methods 25: 402-408, 2001.

10. Panzer A, Joubert AM, Bianchi PC, Hamel E and Seegers JC: The effects of chelidonine on tubulin polymerisation, cell cycle progression and selected signal transmission pathways. Eur J Cell Biol 80: 111-118, 2001.

11. Paul A, Bishayee K, Ghosh S, Mukherjee A, Sikdar S, Chakraborty D, Boujedaini $\mathrm{N}$ and Khuda-Bukhsh AR: Chelidonine isolated from ethanolic extract of Chelidonium majus promotes apoptosis in HeLa cells through p38-p53 and PI3K/AKT signalling pathways. Zhong Xi Yi Jie He Xue Bao 10: 1025-1038, 2012.

12. Havelek R, Seifrtova M, Kralovec K, Krocova E, Tejkalova V, Novotny I, Cahlikova L, Safratova M, Opletal L, Bilkova Z, et al: Comparative cytotoxicity of chelidonine and homochelidonine, the dimethoxy analogues isolated from Chelidonium majus L. (Papaveraceae), against human leukemic and lung carcinoma cells. Phytomedicine 23: 253-266, 2016.

13. Androutsopoulos VP, Tsatsakis AM and Spandidos DA: Cytochrome P450 CYP1A1: Wider roles in cancer progression and prevention. BMC Cancer 9: 187, 2009.

14. El-Kenawi AE and El-Remessy AB: Angiogenesis inhibitors in cancer therapy: Mechanistic perspective on classification and treatment rationales. Br J Pharmacol 170: 712-729, 2013.

15. Vinci M, Box C, Zimmermann $M$ and Eccles SA: Tumor spheroid-based migration assays for evaluation of therapeutic agents. Methods Mol Biol 986: 253-266, 2013.

16. Mehta G, Hsiao AY, Ingram M, Luker GD and Takayama S: Opportunities and challenges for use of tumor spheroids as models to test drug delivery and efficacy. J Control Release 164: 192-204, 2012.

17. Kim O, Hwangbo C, Kim J, Li DH, Min BS and Lee JH: Chelidonine suppresses migration and invasion of MDA-MB231 cells by inhibiting formation of the integrin-linked kinase/PINCH/ $\alpha$-parvin complex. Mol Med Rep 12: 2161-2168, 2015.

This work is licensed under a Creative Commons Attribution-NonCommercial-NoDerivatives 4.0 International (CC BY-NC-ND 4.0) License. 